\title{
UMA ANÁLISE DA AMBIVALÊNCIA DO CONSTITUCIONALISMO
}

\author{
Renata Albuquerque Lima ${ }^{1}$ \\ Centro Universitário Christus (UNICHRISTUS) \\ Ana Paula Marques de Souza ${ }^{2}$ \\ Universidade Estadual Vale do Acaraú (UVA) \\ Sara Alves Magalhães ${ }^{3}$ \\ Universidade Estadual Vale do Acaraú (UVA)
}

\section{Resumo}

O presente estudo objetivou analisar a danos catastróficos. Em termos ambivalência do Constitucionalismo metodológicos, o trabalho apresenta sob o aspecto da legitimação abordagem qualitativa e exploratória, de governos autoritários e $\mathrm{da}$ fundamentação de decisôes judiciais arbitrárias, que visam atender interesses particulares em detrimento do interesse público. Para isso, além dos aspectos introdutórios à compreensão do tema, foram trabalhados dois exemplos que evidenciam a possibilidade efetiva de ocorrência, na prática, da ambivalência do Constitucionalismo: a ditadura nazifascista alemã e a judicialização da política. A análise de fatos pretéritos e contemporâneos auxilia na compreensão de que se trata de um fenômeno recorrente que, embora se apresente inofensivamente em algumas situaçôes, pode provocar sendo o método de pesquisa dedutivo, baseado na pesquisa bibliográfica a respeito do tema. Em síntese conclusiva, verificou-se que o Constitucionalismo, apesar de apresentar uma natureza que visa essencialmente efetivar direitos e garantias fundamentais, pode ser utilizado como meio de opressão pelos detentores do poder mediante interpretaçóes dos dispositivos e princípios constitucionais que sejam convenientes à satisfação de seus interesses.

Palavras-chave: constitucionalismo; direitos fundamentais; judicializaçấo da política; nazismo.

1 Pós-doutora em Direito pela Universidade Federal de Santa Catarina (UFSC). Doutora em Direito Constitucional pela Universidade de Fortaleza (UNIFOR). Professora do Mestrado em Direito e da graduaçáo em Direito da UNICHRISTUS. Professora-adjunta do curso de Direito da Universidade Estadual Vale do Acaraú (UVA). Coordenadora do curso de Direito da Faculdade Luciano Feijão (FLF). E-mail: realbuquerque@yahoo.com

2 Doutoranda em Direito pela Faculdade de Direito de Vitória (FDV). Mestre em Direito pela Universidade Federal da Paraíba (UFPB). Graduada em Direito pela UVA. Advogada. ORCID: http://orcid.org/0000-0003-1667-7940 / e-mail: profa.anapaulamarques@gmail.com

3 Graduada em Direito pela UVA. Advogada. ORCID: http://orcid.org/0000-0001-9643-5276 / e-mail: saramagalhaes@gmail.com 


\section{AN ANALYSIS OF THE AMBIVALENCE OF CONSTITUTIONALISM}

\section{Abstract}

Thisstudy aims to analyze the ambivalence of Constitutionalism under the aspect of the legitimation of authoritarian governments and of the reasoning of arbitrary judicial decisions that aim to serve particular interests over the public interest. For this, beyond the introductory aspects to the understanding of the theme, two examples were used to evidence the actual possibility of occurrence in practice of Constitutionalism's ambivalence: the German Nazifascist dictatorship and the judicialization of politics. The analysis of past and contemporary facts helps to understand that this consists in a recurring phenomenon that, although it seems harmless in some situations, can cause catastrophic damage. In methodological terms, the study presents a qualitative and exploratory approach, with deductive research method, based on bibliographic research of the subject matter. In conclusive summary, it was verified that Constitutionalism, despite having a nature that essentially aims to effectuate fundamental rights and guarantees, can be used as a means of oppression by those in power through interpretations of the constitutional provisions and principles that are convenient to the satisfaction of their interests.

Keywords: constitucionalism; fundamental rights; judicialization of politics; nazism. 


\section{Introdução}

O Constitucionalismo é sustentado, atualmente, como algo essencialmente positivo, sendo definido como um movimento político, ideológico e jurídico que tem por finalidade organizar o Estado e limitar os poderes deste, por meio da previsão de direitos e garantias fundamentais, consignados em uma Constituição - objeto de manifestação do Constitucionalismo -, de modo a evitar arbitrariedades por parte daqueles que se encontram em posição de representantes do povo.

Ocorre que os ideais do referido movimento podem vir a ser manipulados para legitimar governos autoritários e fundamentar decisões arbitrárias, como já ocorreu em momentos históricos anteriores e como ainda ocorre em diversas situações nos presentes dias. O instrumento para realização de tal fim é a interpretação de dispositivos e princípios constitucionais, instrumentalizados tendenciosamente, para atender a interesses particulares em detrimento do interesse público, o que demonstra a postura ambivalente que o Constitucionalismo pode assumir.

Diante disso, o presente estudo objetiva identificar as causas desse fenômeno e apresentar suas consequências, o impacto negativo que a ambivalência do Constitucionalismo pode provocar no âmbito social, jurídico e político, pautando a abordagem de fatos históricos e contemporâneos; colocando-os em paralelo para que evidenciem como o problema permanece atual, apesar dos resultados catastróficos do passado.

Para isso, recorreu-se à abordagem qualitativa e exploratória, sendo o método de pesquisa dedutivo, embasado na pesquisa bibliográfica e na historiografia, posteriormente analisadas, sobre os efeitos no âmbito político-social do ponto de vista jurídico.

A partir da problemática e dos objetivos sucintamente apresentados, pode-se verificar, ainda que de maneira pontual, que o Constitucionalismo pode ser utilizado tanto como instrumento de libertação, como de opressão. Uma base constitucional, ainda que com expressa previsão de direitos e garantias fundamentais, nem sempre garantirá o bem-estar e a paz social à população de um Estado, e pode ser utilizada de maneira insidiosa, favorecendo ideais particulares e afligindo o interesse público, mediante a deturpação da essência do texto constitucional.

\section{Constitucionalismo: origem, conceito, objeto e finalidade}

Para que se compreenda, ao longo deste estudo, os objetivos traçados e os resultados obtidos, é necessário que se faça uma análise introdutória de elementos 
que são essenciais ao tema. Diante disso, faz-se imperioso tratar dos aspectos gerais do Constitucionalismo, no que tange à sua origem, ao seu conceito, ao seu objeto de estudo e à sua finalidade.

\subsection{Evoluçáo histórica}

Inicialmente, é importante destacar que o Constitucionalismo não foi originariamente um movimento uniforme, uma vez que se deu de maneiras, locais, momentos diferentes. Logo, a atual concepção que se tem do Constitucionalismo é resultado de um apanhado histórico-cultural que foi estudado e aperfeiçoado por juristas até os dias atuais - e é constantemente atualizado, sendo o Direito uma faculdade dinâmica.

Assim, em sentido amplo, em uma abordagem histórica acerca da origem do Constitucionalismo, há indícios de que, desde a Antiguidade, estudiosos já defendiam a ideia da existência de um documento que subordinasse todos a suas normas, inclusive as autoridades do Estado.

Sabe-se que as civilizaçóes mais arcaicas possuíram documentos que se assemelhariam à ideia que hoje se tem de Constituição, pois visavam organizar o Estado e também garantir direitos, ainda que de maneira rudimentar, a exemplo do Código de Hamurabi, na Mesopotâmia, e dos limites bíblicos impostos em Estados Teocráticos, como ocorria com os hebreus, uma vez que a Lei do Senhor aplicava-se tanto ao governante como aos governados.

Nesse sentido, segundo Ferreira Filho (2012), desde a Antiguidade, tem-se o entendimento de que, entre as leis, há aquelas que organizam o próprio poder, mediante a fixação de seus órgãos e do estabelecimento de suas atribuiçóes; em síntese, da definição de sua Constituiçãa.

Diante disso, é possível observar que, embora existisse a ideia concreta de um texto normativo hierarquicamente superior e capaz de limitar poderes governamentais e garantir direitos fundamentais, os regulamentos como os entendemos hoje não existiam, efetivamente, à época da Antiguidade, mas outros documentos em moldes primitivos faziam as vezes do que hoje se denomina Constituição.

Já durante a Idade Média e a Idade Moderna, os pactos realizados entre os monarcas e seus súditos mediante acordo de vontades foram os instrumentos garantidores de direitos individuais, entre os quais se destacaram a Magna Carta de 1215 e o Petition of Rights de 1628, marcando, assim, a essência pré-constitucional desses períodos, principalmente no que se refere à Magna Carta de 1215, pois foi o primeiro documento formal a submeter o monarca a suas normas, assim como o povo. 
Entretanto, a mera existência de um documento sem eficácia efetiva de limitação do poder e proteção de direitos fundamentais fez que o período medieval não fosse considerado o marco principal da história do Constitucionalismo. Senão, vejamos:

O princípio da primazia da lei, a afirmação de que todo poder político tem de ser legalmente limitado, é a maior contribuição da Idade Média para a história do Constitucionalismo. Contudo, na Idade Média, ele foi um simples princípio. Muitas vezes pouco eficaz, porque faltava um instituto legítimo que controlasse, baseando-se no direito, o exercício do poder político e garantisse aos cidadãos o respeito à lei por parte dos órgãos do Governo (BOBBIO; MATTEUCCI; PASQUINO, 1998. p. 255).

Parte da doutrina, entretanto, entende que, em sentido estrito, apenas considerar-se-ia como efetivo marco histórico do referido movimento, as revoluçóes político-sociais ocorridas durante o século XVIII, período no qual houve a consolidação da ideia de limitação do poder estatal e a positivação das Constituiçôes "como instrumento para conter qualquer arbítrio decorrente do poder" (LENZA, 2014, p. 68).

O Constitucionalismo, para Moraes (2017), teve sua origem formal vinculada ao surgimento das constituições escritas e rígidas dos Estados Unidos, em 1787, e da França, em 1791, apresentando duas significativas características: a previsão de direitos e garantias fundamentais por meio da organização do Estado e limitação do poder estatal.

Os exemplos supracitados demonstram que não há uma uniformidade de entendimentos doutrinários acerca da origem do Constitucionalismo, entretanto, nenhuma das abordagens, seja no sentido amplo ou estrito, está equivocada. Adota-se neste trabalho, contudo, a abordagem lato sensu por entender que toda a história se interliga - a restrição a um marco histórico determinado é entendido como formalismo acadêmico -, e para ser compreendida, exige o estudo do todo, pois se eventualmente vista de maneira isolada, poderia não ser equivocadamente assimilada.

\subsection{0 que é Constitucionalismo?}

Partindo da compreensão histórica stricto sensu - vez que é a mais utilizada pela doutrina majoritária - que considera as revoluçóes político-sociais do século XVIII como sendo o marco formal da origem do Constitucionalismo, constata-se que no lapso temporal em questão prevalecia o movimento absolutista, no qual 
o monarca possuía poderes ilimitados e incondicionados, sendo sua vontade a própria lei.

Nesse contexto, prevalece na doutrina o entendimento de que o Constitucionalismo é um movimento, normalmente classificado como político, social e/ ou jurídico, que visa limitar o poder dos governantes mediante um documento escrito, chamado de Constituição, com o fim de combater arbítrios políticos e garantir liberdades individuais.

Tavares (2012, p. 23) considera a existência de, pelo menos, quatro definiçôes para o Constitucionalismo, quais sejam:

Numa primeira acepção, emprega-se a referência ao movimento político-social com origens históricas bastante remotas que pretende, em especial, limitar o poder arbitrário. Numa segunda acepção, é identificado com a imposição de que haja cartas constitucionais escritas. Tem-se utilizado, numa terceira concepção possível, para indicar os propósitos mais latentes e atuais da função e posição das constituiçôes nas diversas sociedades. Numa vertente mais restrita, o constitucionalismo é reduzido à evolução histórico-constitucional de um determinado Estado.

Por outro lado, Canotilho (1941, p. 51) defende que "o movimento constitucional gerador da constituição em sentido moderno tem várias raízes localizadas em horizontes temporais diacrónicos e em espaços históricos, geográficos e culturais diferenciados", portanto, para o autor, há vários movimentos constitucionalistas.

Nessa perspectiva, o Constitucionalismo se trata de um conjunto de movimentos que manifestaram a necessidade popular de ter relevância nas decisões políticas do Estado, sem ser subjugada às arbitrariedades dos governantes. Ao fazer valer o controle do poder político mediante a garantia de liberdades e direitos individuais, que seriam, portanto, o limite a ser respeitado pelas autoridades governamentais, quando na tomada de suas decisóes, o povo haveria de ter seus direitos resguardados.

Portanto, partindo do pressuposto de que o objetivo precípuo dos movimentos político-sociais ocorridos durante o século XVIII - os quais seriam o marco histórico determinante para o surgimento efetivo do Constitucionalismo, em uma concepção stricto sensu - era a "transição da monarquia absoluta para o Estado Liberal de Direito” (CARVALHO, 1999, p. 132) por meio da limitaçâo do poder e da garantia de direitos fundamentais. 


\subsection{A Constituiçáo}

A Constituição é tão complexa quanto o próprio Constitucionalismo, pois, uma vez que é o instrumento que materializa ideais que se manifestam de variadas maneiras, enseja discussões teóricas acerca de sua classificação e conceito conforme cada manifestação observada no plano material.

Para este estudo, porém, as mencionadas classificaçôes e definiçóes variadas não serão aprofundadas, pois não são imprescindíveis ao desenvolvimento do tema. Adotar-se-âo, portanto, conceitos de Constituiçáo que se enquadram na linha de raciocínio empregada neste trabalho, com enfoque na noção de sistema jurídico-normativo hierarquicamente superior que rege o poder estatal e assegura direitos fundamentais.

Com base nisso, vejamos a seguinte definição dada à Constituição:

A Constituição do Estado, considerada sua lei fundamental, seria, entâo, a organização dos seus elementos essenciais: um sistema de normas jurídicas, escritas ou costumeiras, que regula a forma do Estado, a forma de seu governo, o modo de aquisiçáo e o exercício do poder, o estabelecimento de seus órgãos e os limites de sua ação, os direitos fundamentais do homem e as respectivas garantias. Em síntese, a constituição é o conjunto de normas que organiza os elementos constitutivos do Estado (SILVA, 2005, p. 37-38).

Bonavides (2012, p. 345), ao falar da necessidade das Constituiçóes, afirma que a Constituição se converte "na imagem da legitimidade nacional, valor supremo que limita todos os poderes e faz impossível o exercício da autoridade despótica, espancando as sombras do arbítrio sempre familiar às ditaduras e aos regimes sem participação popular".

Ademais, Canotilho (1941, p. 52) denomina de constituição moderna "a ordenação sistemática e racional da comunidade política por meio de um documento escrito no qual se declaram as liberdades e os direitos e se fixam os limites do poder político".

Por fim, Carvalho (1999, p. 132-133) afirma que o Constitucionalismo foi o movimento "pelo qual os Estados passaram a adotar leis fundamentais ou cartas constitucionais, reunindo, em um documento escrito sua organização política, bem como a declaração dos direitos dos indivíduos.”.

Analisando os conceitos dados à Constituição por doutrinadores renomados como os supracitados, percebe-se que todos caminham para o sentido de que esta 
é o produto legislativo que funciona como meio de efetivação dos ideais liberais pregados nos movimentos constitucionalistas ocorridos principalmente no século XVIII, decorrente da vontade popular, que se manifesta por meio do poder constituinte originário.

Contudo, conforme propóe o objetivo deste trabalho, será visto mais adiante que embora as Constituiçôes tenham como principal desígnio impedir arbitrariedades por parte dos detentores do poder estatal e assegurar aos cidadáos o gozo de direitos fundamentais, o formalismo, puramente considerado, permitiu que seus princípios e dispositivos fossem utilizados de maneira desvirtuada como meio de legitimação de governos autoritários e de fundamentaçấo de decisóes judiciais arbitrárias.

\subsection{A limitaçáo do poder estatal e a garantia dos direitos fundamentais}

Considerando-se que o Constitucionalismo é a ideia de que a Constituiçáo é o instrumento pelo qual aquela se concretiza no mundo material, deduz-se que a concretização é, na verdade, a ideologia em prática, ou seja, a efetivação de sua finalidade dentro da sociedade.

Sustenta-se que a pretensão da Constituição em sentido moderno é "radicar duas ideias básicas: (1) ordenar, fundar e limitar o poder político; (2) reconhecer e garantir os direitos e liberdades do indivíduo." (CANOTILHO, 1941, p. 54-55).

Nesse sentido, tendo em vista que a limitação do poder estatal e a garantia de direitos fundamentais se mostram como sendo os principais objetivos traçados pelo ideal constitucionalista, eles são a razão da existência desse sistema jurídico.

A respeito desse governo limitado e garantidor de liberdades individuais, Bobbio, Matteucci e Gianfranco (1998, p. 255) afirmam que:

O princípio do Governo limitado torna-se hoje atuante, em primeiro lugar, mediante uma Constituição escrita, que contém variadas normas jurídicas organicamente vinculadas entre si: estas normas não só regulam o funcionamento dos órgãos do Estado, como consagram sobretudo os direitos dos cidadãos, postos como limite ao poder do Estado. A Constituiçáo baseia sua legitimidade em um duplo fundamento: no próprio conteúdo das suas normas, que se impóem por sua intrínseca racionalidade e justiça, e em sua fonte formal, isto é, em sua emanação da vontade direta e soberana do povo, manifesta por meio de uma Assembleia Constituinte e/ou referendum. 
Percebe-se, contudo, que embora a finalidade inicial do Constitucionalismo tenha sido justamente estabelecer limites ao poder do Estado e consagrar direitos dos cidadãos, esta - a finalidade - não visa apenas a esse objetivo, pois os caracteres sociais são mutáveis no espaço e no tempo, fazendo surgir novos anseios, que provocam a evoluçáo da sociedade e do Direito, o que, consequentemente, dinamiza também os objetivos constitucionais.

Assim, em uma definição mais abrangente das finalidades do Constitucionalismo, as quais são efetivadas mediante uma Constituição, Silva (2005) dispõe que o objeto das constituiçôes é estruturar o Estado, organizar seus órgãos, definir o modo de aquisição do poder, o modo como esse será exercido e impor seus limites de atuação, bem como assegurar direitos e garantias individuais, determinar o regime político e regular os fins socioeconômicos estatais e os fundamentos dos direitos econômicos, sociais e culturais.

As Constituições contemporâneas possuem, portanto, caráter polifacético, pois estão "recheadas de normas que incidem sobre matérias de natureza e finalidades das mais diversas, sistematizadas num todo unitário e organizadas coerentemente pela ação do poder constituinte que as teve como fundamentais para a coletividade estatal" (SILVA, 2005, p. 44).

Essa variedade de normas cuja teleologia extrapola a proposta inicial da Constituição - que se limitaria a evitar arbitrariedades governamentais e garantir liberdades individuais -, provocou uma divisão classificatória das constituiçôes entre natureza material ou natureza formal de suas cláusulas.

A doutrina classificada como norma materialmente constitucional é aquela que trata de temas evidentemente constitucionais que sempre estarão ligados à estruturação do Estado e ao funcionamento da ordem política, esteja ela consignada em documento escrito ou não (DUTRA, 2017).

Já por norma formalmente constitucional entende-se como sendo aquela que versa sobre temas que não dizem respeito à matéria constitucional, isto é, "há normas que, mesmo não sendo substancialmente constitucionais, são consideradas constitucionais na medida em que o são formalmente falando" (TAVARES, 2012, p. 88).

Apesar dessa divisão, vale ressaltar que no caso da Constituição da República Federativa do Brasil de 1988, que se trata de uma Constituição escrita e rígida, não há hierarquia entre suas normas, sejam elas de natureza formal ou material, pois se considera que todas as normas nela inseridas "possuem o mesmo valor, a mesma dignidade constitucional, a mesma hierarquia, a mesma supremacia em relaçáo às demais normas do ordenamento jurídico" (DUTRA, 2017).

Assim, depreende-se que atualmente o Constitucionalismo tem diversas 
finalidades, as quais acompanharam a evolução social e as novas pretensôes com ela surgidas, sendo, portanto, uma ideologia dinâmica, podendo-se afirmar que o objetivo primordial dos movimentos liberal-constitucionalistas foi a regulamentação do poder político por meio da garantia de direitos fundamentais, mas que este objetivo foi ampliado, abarcando os mais diversos anseios sociais de acordo com as variaçốes de tempo e espaço.

\section{A influência dos princípios na constituiçáo dos direitos fundamentais}

Assim como o Constitucionalismo, os direitos fundamentais decorrem de um processo histórico-evolutivo, não sendo possível delimitar um marco específico para o seu surgimento. Entretanto, sabe-se que a finalidade principal dos direitos fundamentais é efetivar os ideais que fundamentam o Constitucionalismo, portanto, é garantir a dignidade da pessoa humana por meio da limitação do poder estatal, irradiando-se por todo o ordenamento jurídico-constitucional, impondo aos governantes o dever de abster-se de modo a não contrariá-los e de atuar de modo a efetivá-los (CUNHA JÚNIOR, 2012).

Diante disso, pode-se afirmar que, nesta perspectiva de estudo, os direitos fundamentais teriam o aspecto combinado entre regra e princípio, sendo que a estrutura de regra caracterizaria o aspecto formal do direito fundamental, ao passo que o princípio fundamentaria o aspecto material deste. O distintivo é de que a carga valorativa é excepcional se comparada às demais normas, tornando-os relevantes o suficiente para influenciar na interpretaçáo de todo o ordenamento jurídico.

Percebe-se, desse modo, que há evidente diferencial entre os direitos fundamentais e os demais direitos, por isso ao se fazer necessário um tratamento distinto em relação àqueles, é evidente que possuem carga valorativa superior, o que lhes confere especialidade dentro do ordenamento jurídico, e justifica uma análise mais voltada para os aspectos que demonstram seu elevado teor axiológico.

\subsection{A normatividade dos princípios constitucionais}

Cabe, incialmente, destacar que a ideia que se tinha ao falar de princípios era a de que estes tinham a finalidade única de servir como fonte suplementar de criação e interpretação das normas, tendo prevalecido por muito tempo no estudo do Direito a percepção de que aos princípios incumbia uma função exclusivamente acessória ou complementar, ou seja, atuavam no Direito apenas como mero meio 
de integração diante da existência de possíveis lacunas legislativas.

Ocorre que, com o fortalecimento do pós-positivismo, que consagrou a confluência entre normatividade e eticidade, os princípios passaram a ganhar força normativa dentro da ordem jurídica; e como já integravam as regras, ambos princípios e regras - são espécies do gênero norma, e podem ser classificadas como normas-princípio e normas-regra.

Com base nisso, tem-se que a conquista de força normativo-vinculante pelos princípios dentro da ordem jurídico-constitucional foi de suma importância para o fortalecimento dos direitos fundamentais, pois o caráter valorativo dos direitos fundamentais decorre justamente dos preceitos principiológicos, os quais, reconhecidos pelo movimento neoconstitucionalista, conferem-lhes a especialidade que merecem, colocando-os em destaque no ordenamento jurídico em virtude de sua supremacia formal e material, pois além de constitucionais, são fundamentais.

\subsection{O pós-positivismo e a efetivação dos direitos fundamentais}

O pós-positivismo surgiu como uma "confluência das duas grandes correntes de pensamento que oferecem paradigmas opostos para o Direito: o jusnaturalismo e o positivismo" (BARROSO, 2010, p. 247); com o fim de instituir limites valorativos ao legislador e ao aplicador do direito, uma vez que o jusnaturalismo por si só não seria capaz de manter a ordem jurídico-social e o positivismo isolado deu espaço para a legitimação de arbitrariedades praticadas em nome da lei pura, redigida e aplicada sem considerar princípios, como o da dignidade da pessoa humana.

As ideias pós-positivistas surgem, portanto, como alternativa à insuficiência do positivismo para lidar com as transformaçóes político-sociais ocorridas durante o século $\mathrm{XX}$, período no qual a lei considerada de maneira pura, sem viés valorativo algum, deu espaço para que diversas barbáries fossem cometidas pelos detentores do poder, causando opressão em massa e a violação de diversos direitos fundamentais, como o direito à vida.

Acontecimentos históricos como o nazismo e o fascismo ${ }^{4}$ causaram uma necessidade impetuosa de reestabelecimento da paz social, da limitação do poder estatal e da proteção a direitos básicos do homem. Nesse contexto, o neoconstitucionalismo, movimento constitucional pelo qual o pós-positivismo se expressa, ganhou força como uma tentativa de reparar os arbítrios justificados pelo sistema autoritário que havia se instaurado com base em uma perspectiva extremista do ideal positivista.

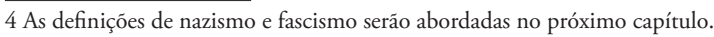


A teoria neoconstitucional visa recuperar a relevância jurídica dos princípios, com o objetivo de reassegurar a dignidade da pessoa humana e, consequentemente, a proteção dos direitos fundamentais, mediante uma interpretação e aplicação mais humanizada da Constituição e das leis (SCHIER; FLORES, 2016).

\subsection{Neoconstitucionalismo: a superaçáo do positivismo jurídico}

Fernandes e Bicalho (2011, p. 04) explicitam que na visão de Kelsen, "o ordenamento jurídico não contemplava uma aplicação valorativa da norma, ou qualquer pauta de correção", pois se restringia ao critério de validade legal e não de matéria, logo, se uma norma fosse válida, "deveria ser aplicada conforme o legislador a concebeu". Desse modo, Kelsen tornou Direito sinônimo de lei, definindo-o como uma ciência pura e livre de interferências extrajurídicas, chegando ao ápice de afirmar que "qualquer conteúdo pode ser Direito" (KELSEN, 1999, p. 139), pois a aferição de validade da norma tem um caráter puramente formal.

Em virtude da propagação desse raciocínio jurídico, tornou-se possível, por exemplo, a legitimação do nazismo na Alemanha - que será abordado de maneira aprofundada no capítulo seguinte -, pois para essa teoria não se deve averiguar se os efeitos do direito no caso concreto são benéficos ou maléficos, justos ou injustos, havendo tão somente a verificação da validade formal da norma, assim, a vigência da corrente positivista serviu como solo fértil para o estabelecimento da ditadura nazifascista.

Embora o positivismo tenha obtido sucesso no que tange a definir o Direito como uma ciência, a efetivar a segurança jurídica e a cingir os excessos da monarquia absolutista, fixando limites plausíveis contra os abusos de poder, não conseguiu promover e garantir a justiça, falhando igualmente ao jusnaturalismo, pecando pelo radicalismo de suas ideais.

Assim, tem-se que o positivismo jurídico conseguiu fragilizar os ideais de limitação do poder estatal e garantia da dignidade humana pregados pelo Constitucionalismo, trazendo a necessidade de um novo movimento que restabelecesse e reforçasse tais ideais após a sucessão de barbaridades legitimadas por leis apáticas, porém com o diferencial de agregar os pontos benéficos das teorias que o antecederam, de modo a garantir a supremacia da norma positivada sem desprezar a necessidade desta em agregar valores que assegurem o bem-estar do homem, por meio do respeito à sua dignidade pelos poderes do Estado.

Nesse contexto, o neoconstitucionalismo surge como um movimento que sucede o constitucionalismo tradicional diante da dinâmica social que passa a clamar 
por novas alternativas de compreensão e organização da ordem constitucional, fazendo-se pôr em prática por intermédio dos ideais pós-positivistas de confluência entre direito e moral, propondo, assim, a reabertura dos sistemas jurídicos para a recepção de princípios, os quais passam a gozar de força normativa suficiente para estabelecer condutas e vincular decisóes, de modo que seja preservada sempre a dignidade da pessoa humana, e que o poder estatal seja exercido respeitando a vontade do verdadeiro detentor do poder, o povo.

\section{Uma análise da ambivalência do Constitucionalismo}

Este capítulo visa analisar casos concretos referentes à relativização da essência do Constitucionalismo e dos direitos fundamentais, que foram empregados com o objetivo de legitimar governos autoritários e fundamentar decisóes arbitrárias, tendo por base dois grandes exemplos a serem minunciosamente analisados nos próximos tópicos, quais sejam, a ditadura nazifascista alemã e a atuação do judiciário brasileiro, notadamente do Supremo Tribunal Federal, o qual já proferiu decisóes fundamentadas sob uma hermenêutica claramente tendenciosa, conforme interesses determinados.

\subsection{Ditadura nazifascista alemá: um regime autoritário formalmente constitucional}

A ascensão do nazismo na Alemanha decorreu de uma série de instabilidades políticas e econômicas que atingiram o país após a Primeira Guerra Mundial, o que deu espaço para que Adolf Hitler e o partido nazista disseminassem suas ideias como solução para recuperar a dignidade do povo alemão, que se encontrava humilhado pelas imposiçóes do Tratado de Versalhes ${ }^{5}$, além de estar acometido pelo desemprego e pela miséria decorrentes das crises que o assolavam o país à época.

O fim da Primeira Guerra Mundial na Alemanha caracterizou-se pelo estabelecimento da República de Weimar, a qual durou de 1919 a 1933, portanto, do pós-guerra ao início do regime nazista, e representou o declínio do Estado Liberal e ascendência do Estado Social, tendo a Constituiçáo de Weimar sido um marco na história do Constitucionalismo, pois viabilizou o estabelecimento dos direitos sociais de segunda geração, aqueles concernentes à cultura, à educação, à previdência e às relaçôes de produçáo e de trabalho, além de ter determinado uma postura ativa ao Estado no que tange à sua atuação para efetivá-los perante a sociedade.

A Constituição de Weimar teve como objetivo reorganizar o Estado alemão,

5 Acordo celebrado pelos países envolvidos na Primeira Guerra Mundial, visando pôr fim ao conflito. É considerado um dos fatores que fortaleceu a ascensão dos nazistas na Alemanha. 
transformando-o em uma República - o funcionamento anterior era um regime imperial -, e estabelecer direitos e deveres fundamentais acrescidos de novos direitos de conteúdo social, fundados em um ideal de democracia. A realidade da crise socioeconômica, caracterizada por altos índices de desemprego e de inflação, impedia que a sociedade alemã visse esperança no novo regime político que tentava se fixar, tendo o discurso nacionalista de Hitler se apresentado como uma solução para superar o colapso pelo qual a Alemanha estava passando.

É nesse contexto de obediência incondicional à lei, desconsiderando qualquer valor moral para fazer valer o texto legal, que se traz à análise o Caso Katzenberger, que representou o fortalecimento da Lei de Proteção Racial (Rassenschutzgesetz) e o rompimento efetivo das relaçôes entre alemães e judeus durante o regime nazista, o que caracterizou evidente violação aos direitos fundamentais de caráter supranacional pelas autoridades alemâs, inspiradas pelo fanatismo e radicalismo que ali se instaurara sob o disfarce de patriotismo e com fundamento nos ideais do positivismo jurídico vigente à época.

O Caso Katzenberger tratou-se da condenação de Lehmann Katzenberger, expoente membro da comunidade judia em Nuremberg, pelo suposto crime de contaminação racial (rassenschande), sob a acusação de que ele havia mantido relações amorosas com uma mulher alemã, Irene Seiler.

Hilberg (2005), em seu livro The Destruction of the European Jews ${ }^{6}$ (título original), faz um estudo aprofundado acerca do extermínio do povo judeu na Europa, analisando os mais diversos casos envolvendo a morte de judeus com fundamento em superioridade racial, social e/ou religiosa, inclusive o "Caso Katzenberger", abordando o processo legal pelo qual passaram Lehmann Katzenberger e Irene Seiler, os constrangimentos provocados pelas autoridades, e a injustiça da condenação. Vejamos:

O exemplo mais flagrante de tal caso, que "levantou uma enorme poeira no sistema judicial", foi a acusaçáo contra Lehmann Katzenberger, chefe da comunidade judaica de Nuremberg. Os fatos deste caso foram os seguintes: em 1932, Katzenberger era o proprietário de um estabelecimento de calçado em Nuremberg. Ele era entâo um homem próspero, cinquenta e nove anos de idade, com filhos já adultos. Neste mesmo ano, uma jovem solteira alemá, com vinte e dois anos de idade, chegou a Nuremberg para administrar uma loja de fotografia no edifício de Katzenberger. O pai da menina pediu-lhe para cuidar dela. Ao longo dos anos, Katzenberger ajudou a menina

6 Trazido para o espanhol por Cristina Piña Aldao, sob o título La Destrucción de los Judíos Europeos, versão utilizada como referência neste trabalho. 
quando teve problemas, ocasionalmente emprestando dinheiro e fazendo pequenos presentes. Essa amizade continuou assim que a moça se casou e depois que a guerra irrompeu. Um dia, a mulher, Sra. Irene Seiler, foi convocada pelo Escritório Distrital do Partido (Kreisleitung), onde foi advertida para interromper o relacionamento. Ela prometeu fazê-lo, mas pouco depois Katzenberger foi preso, para ser julgado por Rassenschande na câmara criminal de um tribunal comum. Katzenberger estava chegando aos setenta anos; a Sra. Seiler tinha mais de trinta anos. [...] No entanto, o juiz que preside o tribunal especial local (Sondergericht, com jurisdição em casos políticos) ouviu sobre a audiência e imediatamente se interessou por ela. Segundo o promotor Markl, este juiz, o Dr. Rothaug, tinha uma disposição "irada”. Ele era um fanático teimoso e estrito que inspirou medo até mesmo de seus promotores. Quando o caso de Katzenberger chamou sua atenção, ele ordenou que o procedimento fosse transferido para sua corte. Nas palavras de outro procurador, Dr. Georg Engert, o juiz Rothaug "reivindicou” o caso para sua corte porque ele estava determinado a não perder a oportunidade de condenar o judeu à morte (HILBERG, 2005, p. 175-176, tradução nossa).

Pela leitura do trecho supracitado, pode-se perceber que um judeu foi condenado à morte por um crime ao qual não cometeu, o que nos evidencia que sua condenação foi dada, sobretudo pelo fato de ser judeu. A clara ausência de provas náo foi suficiente para livrar Lehman Katzenberger da pena de execução e Irene Seiler da prisão por perjúrio. A perseguição aos judeus afetou também alguns alemães que não compactuavam com a ideologia nazista.

Os tribunais nazistas eram rigorosos com relação aos casos de contaminação racial. O processo criminal náo contava com a possibilidade de aplicação de circunstâncias atenuantes, e não havia necessidade de apresentação de provas consistentes para a acusação, pois o ônus probatório recaía sempre para a defesa. Os tribunais sustentavam que qualquer descendente da raça ariana que desejasse relacionar-se com alguém teria o dever legal de verificar se este possuía ariernachweis ${ }^{7}$, de modo a verificar se aquele alguém também era legalmente pertencente à raça ariana. Logo, uma pessoa acusada de infringir a Lei de Proteção Racial não poderia alegar, por exemplo, que desconhecia a situaçáo de seu companheiro com o fim de eximir-se da culpa (HILBERG, 2005).

7 Tratava-se de um certificado ariano, ou seja, um documento que certificava que uma pessoa era um membro da raça ariana na Alemanha nazista. 
Os magistrados, como conhecedores da lei e da justiça e como membros respeitados da sociedade, tinham o dever moral de se opor a tamanhas barbaridades e atrocidades, não podendo jamais invocar o sentimento de amor à pátria para justificar o extermínio de uma raça com o fim de reerguer uma nação, entretanto não se opuseram, o que resultou no fortalecimento da ideologia e no consequente resultado catastrófico obtido.

Diante disso, constata-se que diversos foram os direitos e princípios fundamentais diretamente feridos a fim de "atender aos anseios étnicos da supremacia nazista, episódio historicamente denominado Holocausto" (BREIER, 2015, p. 01). Sendo válido destacar, ainda, que o regime nazista teve suporte legal e constitucional para se legitimar como governo, pois a Constituição de Weimar, segundo Cassilla (2009), embora trouxesse em seu bojo a inovação dos direitos sociais e a organização da Alemanha como um Estado Democrático de Direito, garantiu também prerrogativas de cunho excessivamente autoritário ao chefe de Estado alemáo, a exemplo da possibilidade do Reichspräsident ${ }^{8}$ dissolver o Parlamento (Reichstag), de suspender total ou parcialmente os direitos fundamentais (grundrechte) afirmados na referida Constituição e de utilizar-se das forças armadas para restabelecer a segurança ou a ordem pública, caso estas estejam ameaçadas.

As prerrogativas supracitadas estão presentes nos seguintes dispositivos da Constituição de Weimar:

Artigo 25.

O Presidente do Reich ${ }^{9}$ tem o direito de dissolver o Parlamento, mas apenas uma vez pelo mesmo motivo (ALEMANHA, 1919, tradução nossa).

Artigo 48.

Se um estado não cumpre as obrigaçóes impostas pela Constituição do Reich ou pelas leis do Reich, o Presidente do Reich pode usar a força armada para obrigá-lo a fazer isso.

Caso a segurança pública esteja seriamente ameaçada ou perturbada, o Presidente do Reich poderá tomar as medidas necessárias para restabelecer a lei e a ordem, se necessário usando a força armada. Na prossecução deste objetivo, pode suspender parcialmente ou totalmente os direitos fundamentais descritos nos artigos 114, 115, 117, 118, 123, 124 e 154.

O Presidente do Reich deve informar imediatamente o Reichstag sobre todas as medidas tomadas com base nos parágrafos 1 e 2

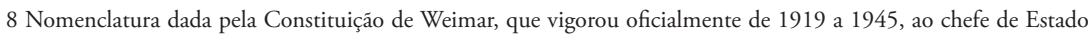
alemão, que em tradução literal para o português significaria: presidente do Reich.

9 Reich significa império. Durante a República de Weimar, o uso do termo continuou apesar do fato de o imperador (Kaiser) ter abdicado. 
deste artigo. As medidas devem ser suspensas imediatamente se o Reichstag assim o exigir.

Se o perigo é iminente, o governo do estado pode, para seu território específico, implementar as etapas descritas no parágrafo 2 . Essas medidas devem ser suspensas, se assim for exigido pelo Presidente do Reich ou pelo Reichstag. Mais detalhes são fornecidos pela lei do Reich (ALEMANHA, 1919, tradução nossa).

Ante um texto constitucional garantidor de prerrogativas tão benéficas ao chefe de Estado, Hitler entendeu desnecessário revogar a Constituição de Weimar para a implantação do regime nazista na Alemanha, pois lhe era assegurado dissolver o Parlamento, suspender direitos fundamentais e utilizar-se da força militar conforme ele entendesse necessário. Além disso, para Hitler, as medidas tomadas por ele caracterizavam-se como algo necessário à naçáo.

É nesse contexto que se verifica a possibilidade de ambivalência do Constitucionalismo, pois os dispositivos supramencionados retirados da legislação constitucional alemã de 1919 tiveram sua essência deturpada para fundamentar crimes contra a humanidade, quando na verdade foram elaborados para garantir a ordem pública e a segurança nacional.

O constituinte originário certamente não elaborou a Constituição de Weimar com o objetivo de embasar um regime autoritário, pelo contrário, visava estabelecer uma ordem democrática na Alemanha, entretanto, proporcionou a possibilidade de se realizar uma exegese tendenciosa que deu margem ao regime antidemocrático, a partir do momento que garantiu ao chefe de Estado faculdades passíveis de arbítrios, tendo o positivismo jurídico assegurado essa exegese deturpada em detrimento de normas cogentes e naturais, como o direito à vida, à dignidade, à liberdade, à crença, entre outros.

Assim, a ditadura nazifascista alemã caracterizou-se por ser um regime autoritário constitucional, ainda que apenas no aspecto formal, residindo aí a possibilidade de ambivalência do Constitucionalismo mediante a utilização de normas constitucionais sem a observância de uma moral superior e alheia às vontades do homem, ou seja, inerente a este e à sociedade como um todo.

\subsection{A judicializaçáo da política: o ativismo judicial como instrumento de efetivaçáo de interesses políticos particulares}

As origens do ativismo judicial estáo estritamente ligadas ao surgimento do pós-positivismo, que visa promover a justiça, mediante a aplicação conjunta de 
princípios, cuja normatividade jurídica deve ser reconhecida; e regras, unindo direito e moral, superando, assim, o pensamento puramente positivista e estendendo as possibilidades da hermenêutica constitucional, a ser realizada pelo aplicador da lei, por meio da concepção de princípios como normas jurídicas, o que permite ao intérprete uma atuação menos restrita no que tange à efetivação de direitos fundamentais, pois a complementação da letra da lei por preceitos principiológicos não a viola, mas a complementa (SANTOS, 2014).

Ocorre que, assim como o ativismo judicial contribui para a promoçáo da justiça e para a efetividade de direitos fundamentais, em virtude da possibilidade de invocar princípios para a complementação do texto legal, este instrumento de atuação do poder Judiciário pode vir também utilizado de maneira tendenciosa ao atendimento de interesses particulares, principalmente no âmbito político, o que provoca a politização da justiça.

Chemim (2017) entende que a interferência de posiçóes político-ideológicas na esfera subjetiva dos magistrados acaba por influenciar o rumo das decisôes proferidas por estes, principalmente quando estão envolvidos temas de grande repercussão social, o que vem a afetar a segurança jurídica e a soberania popular, uma vez que as pressóes político-sociais sobre o Supremo Tribunal Federal interferem no exercício imparcial da funçáo jurisdicional, que passa a ser marcada pelo atendimento de interesses particulares.

Nesse sentido, Boghossian (2018) faz uma crítica ao ativismo judicial seletivo do Supremo Tribunal Federal, uma vez que ele, em determinadas ocasióes, opta por interferir na esfera de atuação dos outros poderes, quando sua intervenção se faz desnecessária, enquanto se omite em alguns casos em que sua intervenção seria necessária.

A título de exemplo desse ativismo judicial seletivo tem-se a invocação, pelo referido Tribunal, do princípio da separação dos Poderes, para fundamentar sua não intervenção na nomeação de Moreira Franco a ministro da secretaria-geral da Presidência da República, durante o governo de Michel Temer, ao passo em que ignorou referido princípio ao anular a nomeaçáo de Lula como ministro da Casa Civil do governo Dilma Rousseff, embora esta tivesse autonomia para tal ato administrativo assim como Michel Temer teve.

Perceba-se que são atos administrativos de competência privativa do chefe do Poder Executivo, entretanto, o Supremo Tribunal Federal, agindo de maneira evidentemente tendenciosa e parcial, invocou o princípio da separação dos Poderes para justificar sua não interferência no primeiro caso e menosprezou a existência do referido princípio ao intervir no segundo.

Portanto, verifica-se que os casos supramencionados de nomeação de 
ministros são bastante semelhantes, porém destinatários de decisôes divergentes, demonstrando uma notória incongruência por parte do Supremo Tribunal Federal na uniformização de seus entendimentos, o que escancara a influência de determinados interesses políticos no fundamento das decisôes, que ora invoca princípios para beneficiar, ora para prejudicar, a depender do interesse envolvido.

A comparaçáo das duas decisóes demonstra o quáo tendencioso e parcial o órgão supremo de proteção da Constituição pode ser, ao ponto de aplicar o texto de um mesmo dispositivo constitucional de maneiras totalmente diferentes em casos semelhantes, considerando a decisão apenas em virtude de influências político-ideológicas. É nessa conjuntura que Streck (2018, p. 01) afirma que "o ativismo sempre é ruim para a democracia, porque decorre de comportamentos e visôes pessoais de juízes e tribunais, como se fosse possível uma linguagem privada, construídas à margem da linguagem pública”.

Em conclusiva, a despeito das críticas apontadas neste capítulo ao ativismo judicial, notadamente no que se refere à judicialização da política, compreende-se que tais fenômenos são relevantes em virtude da dinamicidade do Direito, que evolui conforme as necessidades sociais. Contudo, a discussão objetivada foi a de demonstrar que os instrumentos jurídicos, ainda que criados com um intuito essencialmente assegurador de direitos, podem vir a ser utilizados de maneira contrária, a depender das intençóes do aplicador da lei.

\section{Conclusáo}

Sendo o Constitucionalismo normalmente apresentado pela doutrina como algo essencialmente positivo, levando em consideração que os benefícios trazidos por ele são supervalorizados, este estudo objetivou fazer um contraponto a esta ideia de que se trata de um movimento isento de más consequências, apresentando casos reais que exemplificam as possibilidades do movimento constitucionalista também legitimar ideais nocivos à sociedade.

Partindo desse pressuposto, buscou-se compreender o Constitucionalismo como um todo, desde sua origem à sua finalidade, bem como compreender as correntes de pensamento vigentes em cada período histórico, diferenciando-as e evidenciando seus efeitos no mundo jurídico, em especial no que tange à aplicação da lei, momento que demanda instrumentos hermenêuticos, que se utilizados de maneira artificiosa, podem ser excelentes mecanismos de justificação do desvio da finalidade essencial do texto constitucional, dos direitos fundamentais e dos princípios supralegais.

Essa deturpação da teleologia das leis e dos princípios com o fim de legitimar 
governos autoritários e legitimar decisóes abusivas, foi exemplificada neste trabalho, pela ditadura nazifascista na Alemanha e pela judicialização da política no Brasil, evidenciando-se como tais casos se enquadram nessa concepção de ambivalência do Constitucionalismo.

Assim, diante da análise dos referidos casos, verificou-se que o nazismo era formalmente constitucional, embora inquestionavelmente imoral, arbitrário, injusto e desumano, pois Hitler, por meio de interpretaçóes tendenciosas que se aproveitaram das lacunas deixadas pelo legislador, conseguiu promover o desvio da verdadeira essência da Constituição de Weimar, vigente à época. Já no Brasil, o Supremo Tribunal Federal tem, em algumas ocasiôes, agido de maneira tendenciosa por meio do ativismo judicial na esfera política, provocando a judicializaçáo desta, que tem se caracterizado pelo comprometimento da imparcialidade das decisóes judiciais e da proteção da Constituição, função precípua do órgão supremo do poder Judiciário.

Diante disso, concluiu-se que o Constitucionalismo, a despeito do contexto histórico-social no qual se encontra, estará passível de adquirir um caráter ambivalente, pois diversas são as possibilidades de interpretaçôes dos dispositivos constitucionais, dos direitos fundamentais e dos princípios supranacionais, bastando que o intérprete seja mal intencionado, para que gerem consequências negativas como injustiças sociais, insegurança jurídica e corrupção.

\section{Referências}

ALEMANHA. Weimar Constitution. 1919. Disponível em: https://www.zum.de/ psm/weimar/weimar_vve.php\#Third\%20Chapter. Acesso em: 10 mar. 2019.

BARROSO, L. R. Curso de Direito Constitucional Contemporâneo: os conceitos fundamentais e a construção do novo modelo. 2. ed. São Paulo: Saraiva, 2010.

BOBBIO, N.; MATTEUCCI, N.; PASQUINO, G. Dicionário de Política. 11. ed. Brasília: UnB, 1998.

BOGHOSSIAN, B. Supremo precisa decidir se pode ou não se intrometer em outros Poderes: liberação do indulto de Temer não aplica limitação à atuaçáo política do tribunal. Folha de S.Paulo, 2 dez. 2018. Disponível em: https://www1.folha. uol.com.br/colunas/bruno-boghossian/2018/12/supremo-precisa-decidir-se-pode-ou-nao-se-intrometer-em-outros-poderes.shtml. Acesso em: 12 mar. 2019.

BONAVIDES, P. Teoria geral do Estado. 9. ed. São Paulo: Malheiros, 2012.

BREIER, R. Holocausto e direitos humanos. Canal Ciências Criminais, 13 maio 
2015. Disponível em: https://canalcienciascriminais.com.br/holocausto-e-direitos-humanos/. Acesso em: 10 mar. 2019.

CANOtilho, J. J. G. Direito Constitucional e Teoria da Constituição. 7. ed. Coimbra: Almedina, 1941.

CARvalHO, K. G. Direito Constitucional Didático. 6. ed. Belo Horizonte: Del Rey, 1999.

CASSILLA, L. C. Julgamento de Nuremberg. DireitoNet, 23 nov. 2009. Disponível em: https://www.direitonet.com.br/artigos/exibir/5465/Julgamento-de-Nuremberg. Acesso em: 10 mar. 2019.

CHEMIM, V. A Judicialização da Política e a Politização da Justiça. Estadão, 19 dez. 2017. Disponível em: https://politica.estadao.com.br/blogs/fausto-macedo/a-judicializacao-da-politica-e-a-politizacao-da-justica/. Acesso em: 12 mar. 2019.

CUNHA JÚNIOR, D. Curso de Direito Constitucional. 6. ed. Salvador: Juspodivm, 2012.

DUTRA, L. Direito Constitucional essencial. 3. ed. São Paulo: Método, 2017.

FERNANDES, R. V. C.; BICALHO, G. P. D. Do positivismo ao pós-positivismo jurídico: o atual paradigma jusfilosófico constitucional. Revista de Informação Legislativa, Brasília, v. 48, p. 105-131, abr. 2011.

FERREIRA FILHO, M. G. Curso de Direito Constitucional. 38. ed. São Paulo: Saraiva, 2012.

HILBERG, R. La Destrucción de los Judios Europeos. Madrid: Akal, 2005.

KELSEN, H. Teoria Pura do Direito. 6. ed. São Paulo: Martins Fontes, 1999.

LENZA, P. Direito Constitucional Esquematizado. 18. ed. São Paulo: Saraiva, 2014. MORAES, A. Direito Constitucional. 33. ed. São Paulo: Atlas, 2017.

SANTOS, B. S. A judicialização da política. Público, 27 maio 2003. Disponível em: https://www.publico.pt/2003/05/27/jornal/a-judicializacao-da-politica-201706. Acesso em: 12 mar. 2019.

SANTOS, M. G. Supremo Tribunal Federal, ativismo judicial e a (in)efetividade dos direitos fundamentais. Ambito Jurídico, 1 jul. 2014. Disponível em: https:// ambitojuridico.com.br/cadernos/direito-constitucional/supremo-tribunal-fede- 
ral-ativismo-judicial-e-a-in-efetividade-dos-direitos-fundamentais/. Acesso em: 12 abr. 2019.

SCHIER, A. C. R.; FLORES, P. H. B. Estado de Direito, superação do positivismo e os novos rumos do constitucionalismo. Revista Brasileira de Teoria Constitucional, Curitiba, v. 2, n. 2, p. 1208-1229, dez. 2016.

SILVA, J. A. Curso de Direito Constitucional Positivo. 25. ed. São Paulo: Malheiros, 2005.

STRECK, L. L. O futuro do STF: na retranca, como diz Toffoli, ou no ataque? Conjur, 6 dez. 2018. Disponível em: https://www.conjur.com.br/2018-dez-06/ senso-incomum-futuro-stf-retranca-toffoli-ou-ataque. Acesso em: 12 mar. 2019.

TAVARES, A. R. Curso de Direito Constitucional. 10. ed. Sáo Paulo: Saraiva, 2012. 